\title{
FORMING SOCIAL EXPERIENCE IN MENTALLY RETARDED CHILDREN OF SENIOR PRESCHOOL AGE USING FIGURATIVE ACTIVITIES
}

\section{Tetiana Kuznetsova ${ }^{1}$ Yuliia Amatieva ${ }^{2}$}

DOI: https://doi.org/10.30525/978-9934-26-002-5-5

Forming the social experience of preschoolers is the basis in manifesting social culture, the foundation of their subsequent development, the formation of personality. In the psychological and pedagogical literature, considerable attention is paid to the issue of the formation of social experience in preschoolers and its reflection in various types of activity: speech, play, figurative (L. V. Artemova, A. M. Borodich, O. P. Gavrilushkina, I. A. Groshenkov, D. V. Mendzheritckaia, V. S. Mukhina, S. L. Novoselova, D. B. Elkonin, etc.). In work with the children with intellectual disabilities, this issue is considered as one of the priority areas of correctional-educational work, in which figurative activity is an important component, which allows mentally retarded children to perceive and learn the world around them better [1].

The figurative activity should be considered as a unity of play, speech, and figure (D. B. Elkonin). The children with intellectual disabilities have peculiarities in the development of speech, play, and figurative activity, which makes it difficult to include them in the system of work on the early socialization of preschoolers.

In the figurative activity, an indicative moment of the level of formation of the social experience of children is plot drawing, which makes it possible to understand how a child perceives the world, what he/she knows about it, how he/she relates to it. And accompanying the process of drawing with speech and playing with drawings by children complements the means of expression.

The purpose of the study is to determine the conditions conducive to improving the quality of the content of the drawings of mentally retarded preschoolers through the formation and expansion of their social experience.

At the initial stage, it is required to identify the features of the figurative activity of mentally retarded preschoolers aged from five to seven years old, since it is at this age that the most intensive assimilation of aesthetic and moral criteria that characterize the culture of society takes place, and the plots of the drawings largely depend on the diversity of the child's interaction experience with the surrounding world.

\footnotetext{
${ }^{1}$ SHEI «Donbas State Pedagogical University», Ukraine

${ }^{2}$ Institution of Preschool Education № 9 «Topolka» Dobropilska rada Donetska oblast, Ukraine
} 
Before starting the study, each child was interviewed to identify the level of formation of social experience, knowledge about the surrounding reality, objects, natural phenomena, about social relations. Then the children were offered four series of experimental tasks, involving drawing according to the child's own design, drawing according to the traditional method of «house», «tree», "person», drawing according to a game task, and illustrating a given text, the contents of which reflect the children's playing and everyday experience.

The task of the first stage was to determine the features of drawing on a free concept, which showed the level of formation of the drawing process, namely, the graphic language, the sign function of drawing, the development of imitation. This, to a certain extent, made it possible to judge the level of the intellectual development of children [2]. Besides, the independent choice of the plot indicated the development of the child's imagination and level of social experience.

The task of the second stage of the experiment was to determine the level of formation of subject drawing among preschoolers and their ability to verbally analyze the drawing. For this purpose, the children were asked to draw the objects that they had already drawn in class: a house, a tree, a person. At the end of that work, the teacher asked the child what he/she had drawn and, pointing to various parts of the subject, asked him/her to name them.

The tasks of the third stage were aimed at identifying the level of plot drawing and the ability to use speech as an auxiliary figurative means. The child was given the task to draw how he/she played with a friend. In this case, the children drew based only on personal experience, and the shortcomings of graphic skills had to be complemented by speech.

The task of the fourth stage of the experiment was similar to the third one and consisted of studying the features of the plot drawing on a given topic, close to the play and everyday experience of the children. The children were read a story, according to the plot of which they had to create a drawing.

The analysis of the data obtained showed an insufficient level of the social experience of preschoolers with intellectual disabilities, which had been already revealed in a preliminary conversation. The children's ideas about social life are at a much lower level (16\% of the correct answers) than knowledge about nature (29\%) and the immediate environment (55\%).

The analysis of the first two stages of the experiment made it possible to reveal the objectivity, composition, and emotional content of the drawing. An independent plan, as a rule, was a reflection of the themes of previous lessons. But even when depicting well-known objects, $26.5 \%$ of children could not 
create a subject drawing and, after finishing work, answer the question, «What have you drawn?».

Most of the drawings (67\%) were primitive, fragmentary, lacking, or insignificant in detail. There took place a kind of drawing of separate parts instead of a whole, assimilation, mixing and distortion of the shape of parts of objects, violation of their spatial arrangement, there was a slip from the chosen theme to drawing more familiar or simpler objects.

All the drawings of the mentally retarded preschoolers were, as it were, outside time and space. The children did not convey the characteristic colors of objects in the drawing at all, they drew one-color (74\%), rarely two-threecolor drawings (26\%), distorted the color characteristics of the object (18\%). This indicates that the mentally retarded preschoolers have a very poor understanding of the objects depicted. They conveyed only the echo of the graphic image of the object that they had painted before, while they did not see gross distortions of the shape and color of the objects they depicted, which led to the loss of the similarity of the drawing with the original.

The analysis of the third and fourth stages of the experiment showed an insufficient level of the development of the plot drawing in the mentally retarded senior preschoolers. They could not convey the storyline; they drew individual objects or figures of people (65\%). In some cases, a figure and toys were drawn (10\%), several figures (15\%), several figures and toys $(10 \%)$. Most of the drawings boiled down to listing different objects, not related to each other by a single plot, without reflecting the place and time of what was happening.

The speech accompaniment in the process of drawing was distinguished by the poverty of utterances. In most cases, the children drew in silence or spoke off the topic of the drawing. At the end of that work, they could not give a coherent description of what was depicted, show the dynamics of events, the time of what was happening, they simply listed the objects.

Thus, the preschoolers with intellectual disabilities have insufficient ideas about social phenomena and difficulties in reflecting them in the figurative activity. We have identified the conditions that enhance the quality of the content of their drawings by shaping and expanding their social experience.

It is known that interdisciplinary connections contribute to deeper and more versatile assimilation of the material [3]. The close relationship of the figurative activity and classes on familiarization with the environment, the development of speech, manual labor contribute to deeper cognition of objects, phenomena, social relations, and laws of the objective world, as well as reproduction or creation of something new in the process of the activity.

In classes on familiarization with the environment, the children acquire the necessary stock of knowledge and ideas, the experience that they reflect in 
drawings, and in classes on the development of speech, they learn to convey their impressions first in verbal images, and only then in a drawing.

In classes on the figurative activity of mentally retarded preschoolers, it is necessary to teach specially to reflect in the drawings the impressions they receive when familiarizing themselves with the environment. The basic techniques are the discussion of the future plot, modeling of real situations, element-by-element display of what is depicted, verbal support of the activity, and comparison of the drawing with nature. Then children need teaching to describe their drawings and play around the situations depicted.

Such a system of special techniques will make it possible to intensify work on forming social experience in the preschoolers with intellectual disabilities and to use the knowledge gained in various types of children's activities.

\section{References:}

1. Vysotska, A. M. (2015). Prohrama rozvytku ditei doshkilnoho viku z rozumovoiu vidstalistiu «Formuvannia sotsialnykh navychok». Metodychni rekomendatsii [Program for developing preschool children with mental retardation «Formation of Social Skills»]. Methodical guidelines. Ternopil: Mandrivets. (in Ukrainian)

2. Vygotskii, L. S. (2004). Psikhologiia razvitiia rebenka [Psychology of child development]. Moscow: Izd-vo Smysl, Izd-vo Eksmo. (in Russian).

3. Huriev, A. I. (2002). Status mizhpredmetnykh zviazkiv u systemi suchasnoi osvity [Status of interdisciplinary links in the system of modern education]. Science and School, no. 2, pp. 41-45. (in Ukrainian)

4. Kurienkova, A. V., \& Bondarenko, Yu. A. (2019). Analiz praktyky formuvannia sotsialnoi kompetentnosti u ditei iz intelektualnymy porushenniamy u zakladi doshkilnoi osvity [Analysis of practice of forming social competence in children with intellectual disabilities in institutions of preschool education]. Scientific Journal of the NPU Named after M. P. Drahomanov. Series: Pedagogical Sciences: Realities and Prospects, no. 66, pp. 121-124. (in Ukrainian)

5. Syzko, H. I. (2015). Zasvoiennia suspilnoho dosvidu yak umova efektyvnoi sotsializatsii ditei iz rozumovoiu vidstalistiu [Assimilation of social experience as a condition for effective socialization of children with mental retardation]. Scientific Journal of the NPU Named after M. P. Drahomanov. Series 19. Correctional Pedagogy and Special Psychology, Collection of Scientific Papers, no. 30, pp. 302-307. (in Ukrainian) 